FIU Law Review

Spring 2015

\title{
Federal Preemption of State Regulation of Airline Pricing, Routes, and Services: The Airline Deregulation Act
}

Paul Dempsey

Institute of Air \& Space Law, McGill University

Follow this and additional works at: https://ecollections.law.fiu.edu/lawreview

Part of the Other Law Commons

Online ISSN: 2643-7759

\section{Recommended Citation}

Paul Dempsey, Federal Preemption of State Regulation of Airline Pricing, Routes, and Services: The Airline Deregulation Act, 10 FIU L. Rev. 435 (2015).

DOI: https://dx.doi.org/10.25148/lawrev.10.2.9

This Article is brought to you for free and open access by eCollections. It has been accepted for inclusion in FIU Law Review by an authorized editor of eCollections. For more information, please contact lisdavis@fiu.edu. 


\title{
Federal Preemption of State Regulation of Airline Pricing, Routes, and Services: The Airline Deregulation Act
}

\author{
Paul Stephen Dempsey*
}

The Airline Deregulation Act of 1978 (ADA) included an explicit preemption clause to prevent the states from re-imposing economic regulation on the airline industry. However, that legislation left untouched a provision in the Federal Aviation Act of 1958 which preserved common law remedies. Conflicts between states and passengers, on the one hand, and airlines, on the other, have been fought in federal courts on numerous occasions, and three cases have made their way up to the United States Supreme Court. This article discusses that jurisprudence.

State law is preempted by federal law under the Supremacy Clause of the U.S. Constitution. ${ }^{1}$ Article VI, clause 2, of the U.S. Constitution (the Supremacy Clause) provides:

This Constitution, and the Laws of the United States which shall be made in Pursuance thereof; and all Treaties made, or which shall be made, under the Authority of the United States, shall be the supreme Law of the Land; and the Judges in every State shall be bound thereby, any Thing in the Constitution or Laws of any State to the Contrary notwithstanding. ${ }^{2}$

The Supremacy Clause of the U.S. Constitution "invalidates any state law that contradicts or interferes with an Act of Congress." ${ }^{3}$ As one commentator observed, "[t]he power of the federal government to displace state law in those areas in which Congress has the ability to legislate is a potent one; it divests states of the ability to regulate in an area within the state's domain." 4

The intent of Congress becomes the focus in such analysis. With the gradual recognition of the legitimacy of state police powers, and deferential

* Tomlinson Professor of Law, and Director, Institute of Air \& Space Law, McGill University. A.B.J., J.D., University of Georgia; LL.M., George Washington University; D.C.L., McGill University. The author would like to thank the FIU Law Review staff for its editorial assistance and Dean Alex Acosta for hosting this symposium.

U.S. CONST. art. VI, cl. 2.

Id.

3 Hayfield N. R.R. v. Chicago \& Nw. Transp. Co., 467 U.S. 622, 627 (1984).

4 Susan J. Stabile, Preemption of State Law by Federal Law: A Task for Congress or the Courts?, 40 VILL. L. REV. 1, 90 (1995). 
"rational basis" analysis, the Supreme Court began to retreat from dormant Commerce Clause preemption. Nevertheless, three circumstances exist under which state police power regulation of a matter of local concern will be deemed preempted by federal law:

1. Explicit Preemption-Where Congress explicitly preempts state law; ${ }^{5}$

2. Occupy the Field-Where the scheme of federal regulation is so pervasive as to leave no room for the states to exert jurisdiction; ${ }^{6}$ or in other words, where congressional intent to preempt may be inferred from the existence of a pervasive federal regulatory scheme; ${ }^{7}$ or

3. Same Purpose Covered-Where the object to of the federal law and the character of the obligations imposed thereby address the same purpose as the state regulation; ${ }^{8}$ or in other words, where state law conflicts with federal law or interferes with achievement of congressional objectives. ${ }^{9}$

The Airline Deregulation Act of 1978 was essentially an economic deregulation statute. $^{10}$ It included an explicit preemption provision

5 See Jones v. Rath Packing Co., 430 U.S. 519, 525-26 (1977); Shaw v. Delta Airlines, Inc., 463 U.S. 85, 96 (1983). For example, the General Aviation Revitalization Act of 1994 (GARA) explicitly preempted state common law actions against manufacturers for aircraft manufactured more than 18 years before suit was filed. For a discussion of GARA and federal preemption, see Stephen R. Ginger \& Will S. Skinner, The Preemptive Effect of the Federal Aviation Act: The Question of GARA and Congressional Intent to Occupy the Field of Aviation Safety, 34 ANNALS OF AIR AND SPACE LAW 481, 503 (2009), and Lisa Normand, A Plaintiff's Guide to Surviving the General Aviation Revitalization Act (GARA) Defense: What Works and What Doesn't, 34 TRANSP. L.J. 43, 70 (2007).

6 Fidelity Fed. Sav. \& Loan Ass'n v. de la Cuesta, 458 U.S. 141, 153 (1982) (quoting Rice v. Santa Fe Elevator Corp., 331 U.S. 218, 230 (1947)).

7 Hillsborough Cnty., Fla. v. Automated Med. Labs., Inc., 471 U.S. 707, 714 (1985). For example, in Abdullah v. Am. Airlines, Inc., the plaintiffs alleged that they were injured during a domestic flight when the aircraft encountered turbulence. Abdullah v. Am. Airlines, Inc., 181 F.3d 363, 363 (3d Cir. 1999). The Third Circuit held that "federal law establishes the applicable standards of care in the field of air safety, generally, thus preempting the entire field from state and territorial regulation." $I d$. at 367. The plaintiffs' state law causes of actions were preempted, although the court noted that "Congress found state damage remedies to be compatible with federal aviation standards." Id. at 375. See Andrew J. Harakas, Litigating the Aviation Case: From Pre-trial to Closing Argument 6 (3d ed. 2008); Wells v. Ky. Airmotive, Inc., No. 2012-CA-001894-MR, 2014 WL 4049894, at *5 (Ky. Ct. App. Aug. 15, 2014) ("The field of aircraft safety and operation has clearly been preempted by federal regulation. The scheme of federal regulation in these areas is sufficiently comprehensive to make it reasonable to infer Congress has left no room for supplementary state regulation.”).

8 Pac. Gas \& Elec. Co. v. State Energy Res. Conservation Comm'n, 461 U.S. 190, 204 (1983) (quoting Rice v. Santa Fe Elevator Corp., 331 U.S. 218, 230 (1947)).

9 Pac. Gas \& Elec. Co., 461 U.S. at 204.

10 See e.g., Paul Stephen Dempsey, Airline Deregulation in the United States: Competition, Concentration, and Market Darwinism, 17 ANNALs OF AIR AND SPACE LAW 199 (1992); Paul Stephen Dempsey, Airline Deregulation and Laissez-Faire Mythology: Economic Theory in Turbulence, $56 \mathrm{~J}$. AIR L. \& COM. 305 (1990); Paul Stephen Dempsey, The Rise and Fall of the Civil Aeronautics Board- 
prohibiting a state or a political division thereof to "enact or enforce a law, regulation, or other provision having the force and effect of law related to a price, route, or service of an air carrier."11 The preemption clause of the ADA was designed to prohibit the states from re-establishing economic regulation that the Federal Government had abolished. In other words, the question of whether a state law relates to rates, routes, or services is "whether state law actually 'interferes' with the purposes of the federal statute, in this case airline deregulation." 12 Airline deregulation explicitly was designed to stimulate "efficiency, innovation and low prices as well as variety and quality of air transportation services."13

Opening Wide the Floodgates of Entry, 11 TRANSP. L.J. 91 (1979); see also Hodges v. Delta Airlines, Inc., 4 F.3d 350, 353 (5th Cir. 1993) (quoting Morales v. Trans World Airlines, Inc., 504 U.S. 374, 37879 (1992)) ("Congress enacted the ADA to dismantle the pervasive federal economic regulation of the interstate airline industry. To prevent the states from frustrating the goals of federal deregulation by establishing or maintaining economic regulations of their own, Congress included in the ADA section 1305 , which preempts the states from enforcing any law 'relating to rates, routes, or services' of any air carrier."). As one court noted, "[n]o State shall enact or enforce any law, rule, regulation, standard, or other provision having the force and effect of law relating to rates, routes, or services, of any air carrier." Koutsouradis v. Delta Airlines, Inc., 427 F.3d 1339, 1343 (11th Cir. 2005) (quoting 49 U.S.C. § 41713(b)(1) (1997)) (internal punctuation marks omitted). The term "air carrier" has been interpreted to include foreign air carriers as well as domestic air carriers. See In re Korean Air Lines Co. Antitrust Litig., 567 F. Supp. 2d 1213, 1219 (C.D. Cal. 2008), aff'd in part, vacated in part sub nom; In re Korean Air Lines Co., 642 F.3d 685 (9th Cir. 2011).

1149 U.S.C. $\S 41713$ (b)(1) (1997).

12 Abdu-Brisson v. Delta Air Lines, Inc., 128 F.3d 77, $82-84$ (2d Cir. 1997); see also id. at 84 ("Permitting full operation of New York's age discrimination law will not affect competition between airlines - the primary concern underlying the ADA. Unlike the regulation of marketing practices at issue in Morales or the regulation of frequent flyer programs at issue in Wolens, whether an airline discriminates on the basis of age (or race or sex) has little or nothing to do with competition or efficiency.”). In Malik v. Continental Airlines Inc., a flight attendant informed a passenger that the overhead bin was full and removed her luggage to the belly of the aircraft. Malik v. Cont'l Airlines Inc., 305 F. App'x. 165, 166 (5th Cir. 2008). The luggage was lost and never recovered. Id. Malik brought an action alleging racial and religious discrimination, and conversion and invasion of privacy. $I d$. at 167 . The fifth circuit held that she failed to plead facts proving intentional discrimination. $I d$. at 170 . Further, her claims for conversion and invasion of privacy had a connection to the airline's baggage handling services and therefore were preempted by the ADA. Id. at 168 . However, the lower court's dismissal of her lost luggage claim was reversed on grounds that "federal common law provides airline passengers with a cause of action for lost luggage." Id; see also Casas v. Am. Airlines, Inc., 304 F.3d 517, 521 (5th Cir. 2002) (provision in carrier's Contract of Carriage disclaiming liability upheld as valid if the passenger had notice of the limitation).

13 Morales, 504 U.S. at 378 (internal punctuation marks omitted). Most U.S. Courts of Appeals have construed "service" to mean the provision or anticipated provision of labor from the airline to its customers, such as boarding, baggage handling, food and drink, or other matters distinct from providing the underlying transportation. See Air Transp. Ass'n of Am. v. Cuomo, 520 F.3d 218, 223 (2nd Cir. 2008); Branche v. Airtran Airways, Inc., 342 F.3d 1248, 1257 (11th Cir. 2003); Travel All Over the World, Inc. v. Kingdom of Saudi Arabia, 73 F.3d 1423, 1433 (7th Cir. 1996); Hodges, 4 F.3d 334 at 336-38. Other courts have construed "service" more narrowly, restricting it to "prices, schedules, origins and destinations" but not to include the "provision of in-flight beverages, personal assistance to passengers, the handling of luggage, and similar amenities." Charas v. Trans World Airlines, Inc., 160 F.3d 1259, 1261 (9th Cir. 1998); Duncan v. Northwest Airlines, Inc., 208 F.3d 1112, 1114-1115 (2000); 
The ADA left untouched the general remedies savings clause in the Federal Aviation Act, which provides, "[n]othing contained in this chapter shall in any way abridge or alter the remedies now existing at common law or by statute."14 Yet some courts have tended to construe the ADA preemption provision more broadly than a limitation on state economic regulation of airlines, and have shielded airlines from suit for a broad array of matters touching airline operations. ${ }^{15}$

The United States Supreme Court has decided three cases construing the ADA's preemption provision. The Court has chosen not to limit the preemption to state efforts to implement measures of traditional economic regulation the ADA was promulgated to eradicate, but has gone further. We review the three decisions chronologically.

Under deregulation, some airlines began to engage in various methods of arguably false and misleading advertising that likely would not be tolerated in other industries. This led the National Association of Attorneys General (NAAG) to adopt detailed comprehensive guidelines for advertising and marketing practices in the airline industry in 1987. They required that:

- restrictions on promotional fares be in legible type;

- round-trip purchase requirements be "clear and conspicuous" and include the round-trip price;

- any "sale" or "discount" fares actually represent "a true savings over regularly available air fares";

- any advertised fare "be available in sufficient quantity so as to meet reasonably foreseeable demand," so as to curtail the widespread airline industry practice of "bait and switch"; and

- restrictive changes in the frequent flyer programs be adopted

Taj Mahal Travel, Inc. v. Delta Airlines Inc., 164 F.3d 186, 194 (1998). However, other U.S. Courts of Appeals have embraced a broader definition. See e.g., Hodges v. Delta Airlines, Inc., 44 F.3d 334, 336 (5th Cir. 1995); Smith v. Comair, Inc., 134 F.3d 254, 259 (4th Cir. 1998); Travel All Over The World, Inc. v. Kingdom of Saudi Arabia, 73 F.3d 1423, 1433 (7th Cir. 1996). One court introduced a threepronged test for determining preemption of airline services:

(1) does the alleged tortuous activity involve an "airline service";

(2) does the alleged tortuous activity directly or tenuously affect an airline service; and

(3) is the alleged tortuous activity reasonably necessary to the provision of the airline service?

Rombon v. United Air Lines, Inc., 867 F. Supp. 214, 221-222 (S.D.N.Y. 1994).

1449 U.S.C. $\$ 1506$ (1958).

15 See Smith v. Comair, Inc., 134 F.3d 254 (4th Cir. 1998); Montalvo v. Spirit Airlines, 508 F.3d 464 at 468 (9th Cir. 2007); Greene v. B.F. Goodrich Avionics Sys., 409 F.3d 784 at 795 (6th Cir. 2005); French v. Pan Am Express, 869 F.2d 1 at 5 (1st Cir. 1989); In re Air Crash Disaster at John F. Kennedy International Airport, 635 F.2d 67 at 75 (2nd Cir. 1980); Abdullah v. Am. Airlines, 181 F.3d 363 at 367 (3d Cir. 1999). Curtin v. Port Authority of N.Y. \& N.J., 183 F. Supp. $2 d 664$ at 671 (S.D.N.Y. 2002); see also, Andrew J. Harakas, Litigating the Aviation Case-From Pre-trial to Closing Argument, 3rd ed. (Chicago: Tort Trial \& Insurance Practice Section, American Bar Association, 2008) at 6. 


\section{prospectively only. ${ }^{16}$}

In Morales v. Trans World Airlines, ${ }^{17}$ the U.S. Supreme Court held that the airline fare advertising provisions of the NAAG guidelines were preempted by the ADA. The Court held that the phrase "related to" a price, route, or service, is to be given broad construction, as if it read "has a connection with or reference to" a price, route, or service. ${ }^{18}$ Morales held that state law is "related to" rates, routes, or services if it has a connection with them, but also recognized that "some state actions may affect airline [rates, routes, and services] in too tenuous, remote, or peripheral a manner" to have a preemptive effect. ${ }^{19}$

The Court found that the ADA preempted states "from prohibiting allegedly deceptive airline fare advertisements through enforcement of their general consumer protection statutes." ${ }^{20}$ The preemption provision was included in the Act to "ensure that the States would not undo federal deregulation with regulation of their own." ${ }^{21}$ In the Court's view, the NAAG guideline requirement that advertised fares be available to meet reasonably foreseeable demand "would have a significant impact upon the airlines' ability to market their product, and hence a significant impact on the fares they charge." 22 In dictum, the Court then limited its holding,

16 Morales v. Trans World Airlines, Inc., 504 U.S. 374, 391 (1992).

17504 U.S. 374 (1992). Similarly, in Air Transportation Association of America, Inc. v. Cuomo, the second circuit found that the New York State Passenger Bill of Rights was preempted, holding that "requiring airlines to provide food, water, electricity, and restrooms to passengers during lengthy ground delays does relate to the service of an air carrier and therefore falls within the express terms of the ADA's preemption provision." Air Transp. Ass'n of Am., 520 F.3d at 222.

18 Morales, 504 U.S. at 384 (emphasis added); see also Trans World Airlines, Inc. v. Mattox, 897 F.2d 773 (5th Cir. 1990) (action brought against deceptive fare advertising under Texas Deceptive Trade Practices Act preempted); Wolens v. Am. Airlines, Inc., 589 N.E.2d 533 (Ill. 1992) (contract and fraud actions against airline for retroactive changes in frequent flyer program not preempted), vacated, 506 U.S. 803 (1992); Miller v. Nw. Airlines, 253 N.J. Super. 618 (App. Div. 1992) (negligence and intentional wrongdoing claim against airline for detention prior to boarding by security personnel not preempted).

19 Morales, 504 U.S. at 384 (internal punctuation marks omitted). Earlier cases held that municipal noise regulation, handicapped discrimination actions and state drug use laws were preempted. See Burbank v. Lockheed Air Terminal Inc., 411 U.S. 624 (1973); Hingson v. Pacific Southwest Airlines, 743 F.2d 1408 (9th Cir. 1984) (airline practices regarding seating of handicapped passengers preempted); Anderson v. USAir, Inc., 818 F.2d 49 (D.C. Cir. 1987) (state common law "obligation .. . to provide equal and courteous service to all” preempted). French v. Pan Am Express, Inc., 869 F.2d 1 (1st Cir. 1989) (state drug use laws preempted). But see Minn. Pub. Lobby v. Metro. Airports Comm'n, 520 N.W.2d 388 (Minn. 1994) (noise regulations which do not, directly or indirectly, control or restrict aircraft flight are not preempted). More recent cases have struck down state advertising regulations and state licensing of intrastate air ambulance services. See De Jesus v. Am. Airlines, Inc., 532 F. Supp. 2d 345 (D.P.R. 2007); Med-Trans Corp. v. Benton, 591 F. Supp. 2d 812 (E.D.N.C. 2008).
20 Morales, 504 U.S. at 378.
21 Id.; see also Am. Airlines, Inc. v. Wolens, 513 U.S. 219, 222 (1995).
22 Morales, 504 U.S. at 390. 
proclaiming that it does not "address whether state regulation of the nonprice aspects of fare advertising (for example, state laws preventing obscene depictions) would similarly 'relat[e] to' rates." 23 The Court also insisted that its decision would not give the airlines "carte blanche to lie and deceive consumers; the [U.S. Department of Transportation (DOT) retains the power to prohibit advertisements which in its opinion do not further competitive pricing." ${ }^{4}$ Though Morales was decided in 1992, the DOT did not get around to promulgating full fare disclosure rules until $2011 .^{25}$

After Morales, airlines began raising the preemption defense liberally in a multitude of state law actions, including state common law tort and contract actions. ${ }^{26}$ Some courts held that state tort law claims were preempted by the ADA ${ }^{27}$ Others held that common law breach of contract and intentional infliction of emotional distress claims were preempted. ${ }^{28}$ State law claims against anticompetitive practices surrounding computer reservation systems were preempted, with federal antitrust law deemed the

23 Id.

24 Id.

2514 C.F.R. 399.84 (2011).

26 See e.g., Lathigra v. British Airways PLC, 41 F.3d 535, 540 (9th Cir.1994) (ADA did not preempt state tort actions for negligent reconfirmation; West v. Northwest Airlines, Inc., 995 F.2d 148, 151 (9th Cir.1993) (tort claim for compensatory damages "too tenuously connected to airline regulation to trigger preemption under the ADA"); Dover v. British Airways, PLC (UK), 2013 WL 5970688, *4 (E.D.N.Y.2013) (contractual obligations for fuel surcharge not preempted); Weiss v. El Al Israel Airlines, 309 F. App'x. 483, 484-85 (2d Cir. 2009) (tort claim for failure to seat a booked customer is a "service" and therefore preempted); Jimenez-Ruiz v. Spirit Airlines, Inc., 794 F. Supp. 2d 344, 349 (D.P.R. 2011) (common law negligence claim for personal injury preempted).

27 See Hodges v. Delta Airlines, Inc., 4 F.3d 350, 356 (5th Cir. 1993); O'Carroll v. American Airlines, 863 F.2d 11 (5th Cir. 1989), cert. denied, 490 U.S. 1106 (1989); Smith v. America West Airlines, 4 F.3d 356 (5th Cir. 1993).

28 See Cannava v. USAir, Inc., Civ.A. No. 91-30003-F, 1993 WL 565341, at*7 (D. Mass. Jan. 7, 1993), and Anderson v. USAir, Inc., 619 F. Supp. 1191 (D.D.C. 1985), aff'd, 818 F.2d 49 (D.C. Cir. 1987), in which the court found that an action for outrageous conduct and violation of the common law obligation to "provide equal and courteous service to all" was preempted. In Qayyum v. US Airways, No. 3:08-0996, 2008 U.S. Dist. LEXIS 92365 (S.D. W. Va. Nov. 12, 2008), a passenger was detained while trying to board an aircraft after security agents found facial cream and a bottle of water in his carry-on bag. Initially, the passenger's bag tested positive for explosives, after which the passenger was subjected to more than nine hours of interrogation. After further tests for explosives came up negative, the passenger was given a ticket for the following day's flight. But still, US Airways refused to board the passenger. Mr. Qayyum filed suit. The court dismissed all claims as preempted by the Airline Deregulation Act. The plaintiff's claim of negligence and negligent training and supervision directly implicated a boarding decision, a "service" under the Airline Deregulation Act. Her claim of intentional infliction of emotional harm also relied in part on denied boarding, and was preempted as well. The plaintiff's claims of false accusations and detainment also related to boarding, which "falls squarely within the scope of preemption." Qayyum v. US Airways, No. 3:08-0996, 2008 U.S. Dist. LEXIS 92365 at 12 (S.D. W.Va. Nov. 12, 2008). But see Miller v. Northwest Airlines, 602 A.2d 785 (N.J. Super. Ct. App. Div. 1992) (negligence and intentional wrongdoing claim against airline for detention prior to boarding by security personnel not preempted). 
exclusive means of private enforcement. ${ }^{29}$ One court held that state contract and tort claims for denied boarding compensation were not preempted, although punitive damages for such injuries were. ${ }^{30}$ Other courts have held that common law claims for personal injury are not preempted. ${ }^{31}$

These issues came to a head again before the U.S. Supreme Court in American Airlines v. Wolens, ${ }^{32}$ a class action suit against American Airlines for both an Illinois consumer fraud statute claim and a common law breach of contract claim. ${ }^{33} \mathrm{Mr}$. Wolens argued that American unilaterally and retroactively imposed restrictions on redemption of frequent flyer mileage award travel (specifically, capacity controls and blackout dates) ${ }^{34}$ The Court found the statutory claim to be preempted by the ADA, but did not read the preemption clause "to shelter airlines from suits alleging no violation of state-imposed obligations, but seeking recovery for the airline's breach of its own, self-imposed undertakings." ${ }^{35}$ It found that "[m]arket efficiency requires effective means to enforce private agreements." Contractual claims, said the Court, "are privately ordered obligations" and therefore do not consist of a state's enactment or enforcement of any law, regulation, or standard having the force and effect of law within the scope of the ADA's preemption provision. ${ }^{37}$ The Court also observed that the USDOT was not equipped either with "the authority [or] the apparatus required to superintend a contract dispute resolution regime." ${ }^{38}$ Hence, if common law contract claims were preempted, a plaintiff would be without recourse, for neither the USDOT nor state courts could adjudicate a contractual dispute. Thus, a state consumer protection or anti-fraud statute or regulation is preempted by the federal ADA; a state common law cause

29 Frontier Airlines, Inc. v. United Air Lines, Inc., 758 F. Supp. 1399 (D. Colo. 1989).

30 West v. Nw. Airlines, Inc., 995 F.2d 148 (9th Cir. 1993).

31 Branche v. Airtran Airways, Inc., 342 F.3d 1248, 1253 (11th Cir. 2003) ("[S]tate law personal injury actions generally have been held not to be preempted under the ADA ...."); see also Benjamin v. Am. Airlines, Inc., No. CV 213-150, 2014 WL 3365995, at*8 (S.D. Ga. Jul. 9, 2014).

32 Am. Airlines, Inc. v. Wolens, 513 U.S. 219 (1995).

33 Id.

34 See Westways World Travel, Inc. v. AMR Corp., 265 F. App'x 472 (9th Cir. 2008) (reversing a district court decision to grant summary judgment on the basis of preemption of a contract claim). But see Hanni v. Am. Airlines, Inc., No. C 08-00732 CW, 2008 U.S. Dist. LEXIS 58613, at*3 (N.D. Cal. Jul. 11, 2008) (holding that the plaintiff's breach of contract claim was preempted by the ADA "to the extent it was based on a breach of the implied covenant of good faith and fair dealing").

35 Wolens, 513 U.S. at 220, 249-50; see also Gordon v. United Cont'l Holding, Inc., No. 2:13CV-05967-SDW-MCA, 2014 WL 4354067, at *4 (D.N.J. Sept. 3, 2014). For a review of both the Morales and Wolens cases, see Jonathan Blacker, "Fly To London for \$298": The Battle Between Federal and State Regulation of Airfare Advertising Heats Up, 61 J. AIR L. \& COM. 205 (1995).
36 Wolens, 513 U.S. at 230.
37 Id. at 228-29.
38 Id. at 232. 
of action in tort or contract apparently is not. ${ }^{39}$

The most recent Supreme Court decision on the issue is Northwest, Inc. v. Ginsberg, ${ }^{40}$ decided in April, 2014. Rabbi S. Binyomin Ginsberg was a Platinum Elite member of Northwest Airline's WorldPerks frequent flyer program. ${ }^{41}$ Northwest Airlines became exasperated with Ginsberg's repeated claims for compensation, saying, "[y]ou have contacted our office 24 times since December 3, 2007 regarding travel problems, including 9 incidents of your bag arriving late at the luggage carousel.... We have awarded you $\$ 1,925.00$ in travel credit vouchers, 78,500 WorldPerks bonus miles, a voucher extension for your son, and $\$ 491.00$ in cash reimbursements." ${ }^{42}$ The airline had had enough. Under the terms of the WorldPerks program, Northwest unilaterally cancelled Ginsberg's membership on grounds that he had abused the program. ${ }^{43}$

Ginsberg filed a class action lawsuit seeking more than five million U.S. dollars in damages as well as injunctive relief restoring his membership in the WorldPerks program and prohibiting Northwest from future revocations of membership. ${ }^{44}$ The District Court held that his claims for breach of the covenant of good faith and fair dealing, negligent misrepresentation, and intentional misrepresentation all were preempted by the ADA as related to Northwest's rates and services. ${ }^{45}$ Ginsberg's remaining claim for breach of contract was dismissed without prejudice, finding no breach inasmuch as the frequent flyer agreement gave Northwest sole discretion to determine whether a customer had abused the program. Ginsberg appealed the breach of the duty of good faith and fair dealing claim, but not the other dismissed claims. On appeal, the U.S. Court of Appeals for the Ninth Circuit reversed, concluding that a breach of an implied covenant claim is "too tenuously connected to airline regulation" to warrant invocation of the ADA's preemption provision. ${ }^{46}$

The Supreme Court disagreed, unanimously reversing the Ninth

39 See Paul Stephen Dempsey \& Laurence Gesell, Public Policy and the Regulation OF COMMERCIAL AVIATION 577-82 (2013).

40 Nw., Inc. v. Ginsberg, 134 S. Ct. 1422 (2014).

41 Id. at 1426.

42 Id. at 1427.

43 Id. Similarly, in Alaska Airlines, Inc. v. Carey, No. C07-5711 RBL, 2008 U.S. Dist. LEXIS 88486 , at $* 2$ (W.D. Wash. Jul. 11, 2008), an airline brought an action against a travel agency, alleging misuse of frequent flyer program benefits. The travel agency counterclaimed, alleging fraud, conversion, defamation, and tortious interference with business expectancy, as well as violating the antitrust laws. $I d$. at $* 11$. With the exception of the antitrust claims, all other counterclaims were deemed preempted by the Airline Deregulation Act. Id.

44 Ginsberg, 134 S. Ct. at 1427.

$45 \quad 49$ U.S.C. $\S 41713$ (2014).

46 Ginsberg v. Nw., Inc., 695 F.3d 873, 879 (2012), rev'd, 134 S. Ct. 1422 (2014). 
Circuit's decision. It first found that the ADA's preemption provision is not limited to legislation or regulations promulgated by a state legislature or regulatory agency, respectively. Instead, the Court concluded that state common law rules "fall comfortably within the language of the ADA preemptive provision," for they have "the force and effect of law." ${ }^{\text {" Th }}$ Though a common law rule is a judicially-created standard, the Court held that, "[w] hat is important ... is the effect of a state law, regulation, or provision, not its form, and the ADA's deregulatory aim can be undermined just as surely by a state common-law rule as it can by a state statute or regulation. ${ }^{, 48}$ Because the implied covenant of good faith and fair dealing at issue was a state-imposed obligation which the parties could not contract away - for the doctrine expanded the parties' voluntarily agreed contractual obligations - and because the claim for frequent flyer eligibility related to airline pricing and service, the Court dismissed the breach of covenant claim. ${ }^{49}$ But in dictum, the Court noted that had Ginsberg pursued his breach-of-contract claim, he might have been able to prove that Northwest did not have unfettered discretion to terminate his membership in the WorldPerks frequent flyer program. ${ }^{50}$ Hence, voluntary contractual undertakings between passengers and airlines appear to withstand preemptive challenges. ${ }^{51}$ Common law doctrines used to expand obligations beyond those voluntarily agreed to are preempted. Thus, under Ginsberg, presumably an allegation of unconscionability of an oppressive contractual term may be preempted.

Numerous courts have recognized that state tort actions surrounding aircraft crashes, ${ }^{52}$ state tort actions against carriers for intentional infliction of emotional harm, ${ }^{53}$ state tort and contract actions brought by passengers

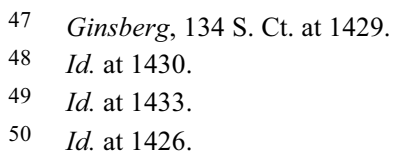

51 See, e.g., Butler v. United Air Lines, Inc., No. C 07-04369 CRB, 2008 U.S. Dist. LEXIS 36646 (N.D. Cal. May 5, 2008) (plaintiff's contract and fraud claims not preempted); Feldman v. United Parcel Serv., Inc., No. 06 Civ. 2490 (MHD), 2008 U.S. Dist. LEXIS 30637 (S.D.N.Y. Mar. 17, 2008) (state law contract claims not preempted); Nippon Fire and Marine Ins. Co. v. Skyway Freight Sys., Inc., 235 F.3d 53 (2d Cir. 2000) (breach of contract claims not preempted, but state law insurance law contract claim preempted).

52 Bieneman v. Chi., 864 F.2d 463, 471 (7th Cir. 1988); see also Stewart v. Am. Airlines, Inc., 776 F. Supp. 1194 (S.D. Tex. 1991) (negligence action for injuries suffered when nose wheel collapsed not preempted). But see Cathedral of Hope v. FedEx Corp. Serv., No. 3:07-CV-1555-D, 2008 U.S. Dist. LEXIS 43031 (N.D. Tex. May 30, 2008) (negligence and gross negligence claims preempted).

53 Hingson v. Pac. Sw. Airlines, 743 F.2d 1408, 1416 (9th Cir. 1984). But see Anderson v. USAir, Inc., 619 F. Supp. 1191, 1197 (D.C. 1985), aff'd, 818 F.2d 49 (D.C. Cir. 1987) (finding that an action for outrageous conduct and violation of the common law obligation to "provide equal and courteous service to all" was preempted). 
"bumped" from flights as a result of deliberate overbooking, ${ }^{54}$ and discrimination suits ${ }^{55}$ are not preempted, unless the passenger had already accepted the airline's offer of alternative transportation. ${ }^{56}$ Some courts have held that actions for compensatory damages, ${ }^{57}$ punitive damages ${ }^{58}$ and state laws authorizing recovery of attorneys' fees ${ }^{59}$ are not preempted. The majority rule appears to be that state common law tort and contract law in areas of comprehensive federal safety regulation are not preempted. ${ }^{60}$ One court noted, "[t]he body of case law is replete with post-ADA cases in which courts have recognized that personal injury negligence claims against airlines are governed by state law." ${ }^{61}$

It is difficult not to side with a company when customers abuse privileges granted to them to such an extent that the company would prefer

54 West v. Nw. Airlines, Inc., 995 F.2d 148, 152 (9th Cir. 1993) (but punitive damages are preempted).

55 Air Transp. Ass'n of Am. v. San Francisco, 266 F.3d 1064, 1072-73 (9th Cir. 2001). In AlWatan v. American Airlines, Inc., the passengers, all of Iraqi descent, were removed from the aircraft after the pilot expressed his belief that they were security risks. Al-Watan v. Am. Airlines, Inc., $570 \mathrm{~F}$. Supp. $2 d$ 925, 927 (E.D. Mich. 2008). The court found that 49 U.S.C. $§ 44902$ (b) affords the pilot wide discretion in determining which passengers might constitute a security risk to passengers and crew. $I d$. at 929. However, the court also found that the plaintiffs' false imprisonment claim was not preempted by the ADA because that statute "is intended to preempt economic regulation by states[, but] is not a safe harbor for airlines from civil tort claims." Id. at 938. The plaintiffs' intentional infliction of emotional distress claim was not preempted where the passenger alleges he was held without any legitimate safety or security reason. $I d$. at 939 . Moreover, the court held that the ADA "does not generally preempt negligence actions against airlines based upon theories of failure to train and failure to supervise if those actions are not related to the airline's rates, routes, or services." Id. at 940.

56 See Christensen v. Nw. Airlines, Inc., 633 F.2d 529, 530 (9th Cir. 1980); Wasserman v. Trans World Airlines, Inc., 632 F.2d 69, 71 (8th Cir. 1980).

57 In re Air Crash Disaster at John F. Kennedy Int'l Airport, 635 F.2d 67, 74 (2d Cir. 1980).

58 In re Air Crash Disaster at Sioux City, Iowa, 734 F. Supp. 1425, 1428 (N.D. Ill. 1990); In re Air Crash Disaster at Stapleton Int'l Airport, 721 F. Supp. 1185, 1187 (D. Colo. 1988).

59 Samtech v. Fed. Express Corp., No. H-03-24, 2004 U.S. Dist. LEXIS 27130 at *1 (S.D. Tex. Mar. 14, 2004).

60 See Cleveland v. Piper Aircraft Corp., 985 F.2d 1438, 1442 (10th Cir. 1993); Pub. Health Trust of Dade Cnty., Fla. v. Lake Aircraft, Inc., 992 F.2d 291 (11th Cir. 1993); Air Crash Disaster at John F. Kennedy Int'l Airport, 635 F.2d at 74-75; In re Mexico City Aircrash v. Western Airlines, Inc., 708 F.2d 400, 407 (9th Cir. 1983) (dictum).

61 Holmes v. United Airlines, Inc., 2012 U.S. Dist. LEXIS 8732 at *13 (N.D. Ill. 2012), and cases cited therein. Some courts have held that actions for compensatory damages, punitive damages, and state laws authorizing recovery of attorneys' fees are not preempted. In re Air Crash Disaster at John F. Kennedy Int'1 Airport, 635 F.2d at 74 (2d Cir. 1980); see also Air Crash Disaster at Sioux City, Iowa, 734 F. Supp. At 1428; In re Air Crash Disaster at Stapleton Int'l Airport, 721 F. Supp. 1185, 1187 (D. Colo. 1988); Samtech v. Fed. Express Corp., No. H-03-24, 2004 U.S. Dist. LEXIS 27130 (S.D. Tex. Mar. 14, 2004). See generally Butler v. United Airlines, No. C 07-04369 CRB, 2008 U.S. Dist. LEXIS 36646 (N.D. Cal. May 5, 2008) (plaintiff's contract and fraud claims not preempted); Feldman v. United Parcel Serv., No. 06 Civ. 2490 (MHD), 2008 U.S. Dist. LEXIS 30637 (S.D.N.Y. Mar. 17, 2008) (state law contract claims not preempted); Nippon Fire and Marine Ins. Co. v. Skyway Freight Sys., Inc. 235 F.3d 53 (2d Cir. 2000) (breach of contract claims not preempted, but state law insurance law contract claim preempted). 
to no longer have them as customers. Yet it seems that the Supreme Court has taken the ADA's preemption provision well beyond the effort of Congress to circumscribe states' ability to regulate intrastate airline entry and pricing. It is to be remembered that the savings clause of the Federal Aviation Act provides that "[n]othing contained in this chapter shall in any way abridge or alter the remedies now existing at common law or by statute." ${ }^{, 2}$ Arguably, the ADA supernova has now emasculated that provision. 